\title{
Pectinase-Ultrasound Synergistic Extraction of Chlorogenic Acid from Flos Lonicera Japonicae
}

\author{
Yang Sun ${ }^{1}$, Hongyue Chen ${ }^{2}$, Chao $\mathrm{Xu}^{2}$, Dinghua $\mathrm{Yu}^{2}$ and $\mathrm{Yi} \mathrm{Hu}^{1^{*}}$
}

${ }^{1}$ School of Pharmaceutical Sciences, Nanjing Tech University, Nanjing, China

${ }^{2}$ Biotechnology and Pharmaceutical Engineering, Nanjing Tech University, Nanjing, China

*Corresponding author: Yi Hu, School of Pharmaceutical Sciences, Nanjing Tech University, Nanjing, China, Tel: 86-25-58139152; E-mail: huyi@njtech.edu.cn

Received date: June 06, 2018; Accepted date: June 12, 2018; Published date: July 12, 2018

Copyright: (c) 2018 Sun Y, et al. This is an open-access article distributed under the terms of the Creative Commons Attribution License, which permits unrestricted use, distribution, and reproduction in any medium, provided the original author and source are credited.

\begin{abstract}
A pectinase-ultrasound synergistic extraction (PUSE) method was developed to extract chlorogenic acid (CGA) from Flos Lonicerae Japonicae (FLJ). The screening and optimization experiments revealed that $20 \%(\mathrm{v} / \mathrm{v})$ ethanol concentration in conjunction with an ultrasonic power $90 \mathrm{~W}$ was the optimal condition. Moreover, other parameters including pectinase concentrations, liquid-solid ratio, ultrasonic time and $\mathrm{pH}$ were systematically optimized. The scanning electronic micrographs revealed that the treatments with pectinase and ultrasound distinctly facilitated the extraction process, in which the plant cell wall was destructed in large extent. Compared with other previously reported methods, PUSE was more efficient with higher CGA extraction yield and CGA yield can reach 5.13\%.
\end{abstract}

Keywords: Ultrasound; Pectinase; Extraction; Chlorogenic acid; Flos Lonicerae Japonicae

\section{Introduction}

FLJ was known as golden-and-silver honeysuckle with sweetly vanilla scented $[1,2]$. As both food and medicinal plants, it has been reported to have multiple biological activities and it is applied in traditional Chinese medicine to treat fever, headache, thirst and carbuncles [3,4]. As main bioactive component of FLJ, CGA has been reported to have multiple pharmacological and biological activities. CGA slightly reduces blood pressure and it has been investigated for anti-inflammatory effects taken as a dietary supplement or in coffee $[5,6]$. A series of methods for CGA extraction including ultrasonic assisted extraction (UAE) [7-9], enzyme extraction (EE) [10,11], water extraction (WE) [12,13], refluent ethanol extraction (REE) [14-16] and microwave-assisted extraction (MAE) $[17,18]$ had been reported. Nonetheless, these methods usually have limitations, such as relative long extraction time and unsatisfactory CGA yield. Therefore, the article developed a new method called pectinase-ultrasound synergistic extraction (PUSE) for the extraction of CGA from FLJ.

\section{Experimental}

\section{Reagents and materials}

FLJ was acquired from Xinyi Honeysuckle Agricultural Development Co., Ltd. (Xinyi, Jiangsu). FLJ with diameters of 1.5-3.0 $\mathrm{mm}$ was dried in hot air oven for extraction. CGA standard was obtained from Aladdin (Shanghai, China). Pectinase was obtained from Shanghai Yuan ye Biotechnology Co., Ltd. (Jiangsu China). Sample solutions were prepared with deionized water. All other reagents are of analytical grade.

\section{Analysis method}

An Amethyst $\mathrm{C}_{18}-\mathrm{H}$ column, $(4.6 \mathrm{~mm} \times 250 \mathrm{~mm}, 5 \mu \mathrm{m})($ Sepax Technologies, Inc.) was used to detected CGA content. The elution was performed in gradient mode using methanol-water as the mobile phase and monitored at a wavelength of $327 \mathrm{~nm}$. Standard curve for CGA was linear at a range of $0.01-1 \mathrm{mg} / \mathrm{ml}$. The CGA yield was calculated using a standard formula: $y=0.999 x+1.296\left(r^{2}=0.999 ; x\right.$, concentration in $\mathrm{g} / \mathrm{ml}$; $\mathrm{y}$, peak area).

\section{Extraction process optimization}

Studies have shown that the activity of pectinase is greatly affected by ultrasound power and ethanol concentration, so a series experiments were conducted to investigate these two factors.

Screening of ethanol concentration: Ethanol with concentrations of $0,10,20,30,40,50,60$ and $70 \%(\mathrm{v} / \mathrm{v})$ and were mixed with $80 \mathrm{mg}$ of pectinase in a flat-bottomed flask to obtain ethanol-pectinase solution with a concentration of $1 \mathrm{mg} / \mathrm{ml}$. After ethanol-pectinase solution $\mathrm{pH}$ was adjusted to 3 , the flasks were placed in a $40^{\circ} \mathrm{C}$ ultrasonic bath for $100 \mathrm{~min}$. The resulting pectinase solution was subsequently used for analysis by hypoiodite method. Similarly, $2.0 \mathrm{~g}$ FLJ powder was mixed with eight different ethanol concentrations from $0-70 \%(v / v)$ and the final extract were filtered through a $0.45 \mu \mathrm{m}$ filter prior for subsequent analysis.

Screening of ultrasonic power: Eighty milligrams pectinase and $20 \%$ $(\mathrm{v} / \mathrm{v})$ ethanol were mixed in a flat-bottomed flask and ethanolpectinase solution mixture with a concentration of $1 \mathrm{mg} / \mathrm{ml}$ was obtained. The flask was placed in an ultrasonic bath and operated at different ultrasonic powers including 60, 75, 90, 105, 120, 135, 150 and $200 \mathrm{~W}$ for $100 \mathrm{~min}$ after the ethanol-pectinase solution $\mathrm{pH}$ was adjusted to 3 . The resulting pectinase solution was used for subsequent analysis by hypoiodite method. Similarly, $2.0 \mathrm{~g}$ FLJ was mixed with eight different ethanol concentrations and the extract was filtered through a $0.45 \mu \mathrm{m}$ filter for subsequent analysis. 
Determination of pectinase activity: Important factors affecting pectinase activity including ethanol concentrations and ultrasonic power were optimized. Pectinase activity was determined by hypoiodite method. Pectinase activity is correlated with the quantity of galacturonic acid and the pectinase activity was calculated by Eq. (1):

$$
\text { Pectinase activity }=\frac{(B-A) \times N \times 0.51 \times S}{E \times t \times M} .
$$

In the equation, $\mathrm{B}$ is the consumption of $\mathrm{Na}_{2} \mathrm{~S}_{2} \mathrm{O}_{3}$ in control, $\mathrm{A}$ is the consumption of $\mathrm{Na}_{2} \mathrm{~S}_{2} \mathrm{O}_{3}$ in sample, $\mathrm{N}$ is $\mathrm{Na}_{2} \mathrm{~S}_{2} \mathrm{O}_{3}$ equivalent concentration, 0.51 is a constant ( $1 \mathrm{mg}$ of equivalent $\mathrm{Na}_{2} \mathrm{~S}_{2} \mathrm{O}_{3}$ equals to $0.51 \mathrm{mg}$ of equivalent free galacturonic acid), $\mathrm{S}$ is the total reaction liquid volume, $\mathrm{E}$ is the volume of enzyme used, $\mathrm{t}$ is the holding time, and $M$ is quantity of absorbing reaction. The amount of enzyme produced in the enzymatic reaction that is equivalent to $1 \mu \mathrm{g}$ of galacturonic acid per minute is defined as 1 enzyme activity unit (U).

Pectinase Ultrasound Synergistic Extraction (PUSE): In addition to the two sensitive factors of ultrasound power and ethanol concentration, other important factors affecting the extraction CGA yield were examined. Certain amount of pectinase was accurately weighed and various concentrations of pectinase aqueous solution $(0-0.7 \mathrm{mg} / \mathrm{ml})$ were prepared. The solutions $\mathrm{pH}$ was then adjusted from 2.0 to $6.0,2.0 \mathrm{~g}$ dried sample was mixed with ethanol-pectinase aqueous solvent and then placed in a KQ-5200DE ultrasonic bath at $40^{\circ} \mathrm{C}$ for $30 \mathrm{~min}$ to $4 \mathrm{~h}$. The extract was subsequently filtered and the residue was discarded. The filtrate was concentrated to $15 \mathrm{ml}$ for subsequently diluted by 625 times using a $1 \mathrm{ml}$ aliquot. The final extract was filtered through a $0.45 \mu \mathrm{m}$ filter for subsequent analysis. All experiments were performed in duplicate.

Scanning electron micrographs of different samples: The structural change of the FLJ powder after the treatment was examined using a
TM3000 tabletop scanning electron microscope (Hitachi, Japan) under high vacuum of $15.0 \mathrm{kV}$.

\section{Results and Discussion}

Pectinase activity had an impact on CGA extraction yield on certain extent. Two important factors impacting pectinase activity including ethanol concentration and ultrasonic power were investigated. Additionally, other factors including pectinase concentration, liquidsolid ratio, ultrasonic time and $\mathrm{pH}$ value were also studied.

\section{Screening of ethanol concentration and ultrasonic power}

CGA is a polar substance and ethanol was used as the extraction solvent (accordingly to the compatibility principle). A serious of experiment on optimizing ethanol concentration was conducted because ethanol concentration had a great influence on enzyme activity [19]. The influences of different ethanol concentrations on enzyme activity were determined under the following conditions: ultrasonic temperature 40, ultrasonic power $75 \mathrm{~W}$, pectinase concentration $1 \mathrm{mg} / \mathrm{ml}$, liquid ratio $40 \mathrm{ml} / \mathrm{g}$, ultrasonic time $100 \mathrm{~min}$ and $\mathrm{pH}$ 3. The results showed that the effect of ethanol concentration $(0-45 \%)$ on the activity of pectinase gradually increased (Figure 1$)$ and the effect of ethanol concentration in this range on the extraction CGA of CGA also gradually increased (Figure 2). In addition, the pectinase activity was steeply declined when ethanol concentration was over $45 \%$ (v/v) (Figure 1a), whereby CGA yield was slightly increased (Figure 2a) and it is likely that the dissolution of ethanol may play a major role in this phase. When ethanol concentration exceeded $80 \%(\mathrm{v} / \mathrm{v})$, pectinase was completely inactivated.
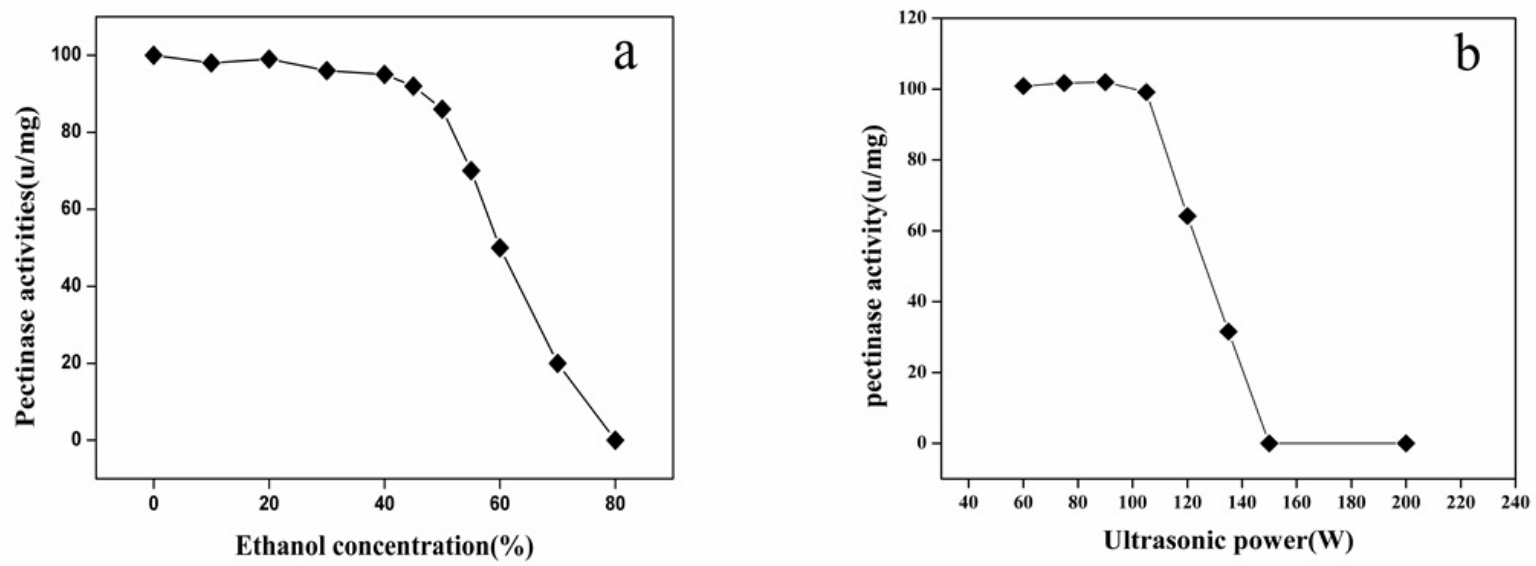

Figure 1: (a) Effects of ethanol concentration on pectinase activity (b) and ultrasonic power on pectinase activity.

It was reported that the ultrasound power had a significant effect on the pectinase activity and it could accelerate the isomerization of unsaturated double bonds and ester bonds of CGA [20,21]. Thus, it is necessary and meaningful to measure pectinase activity and CGA yield under different ultrasonic power. The impacts of different ultrasonic powers on enzyme activity were investigated under conditions as follows of ultrasonic temperature $40^{\circ} \mathrm{C}, 20 \% \quad(\mathrm{v} / \mathrm{v})$ ethanol concentration, $1 \mathrm{mg} / \mathrm{ml}$ pectinase concentration, liquid ratio $40 \mathrm{ml} / \mathrm{g}$, ultrasonic time $100 \mathrm{~min}$, and $\mathrm{pH}$ 3. Although the CGA yield was slightly increased (Figure $2 \mathrm{~b}$ ), the ultrasonic power from 60 to $100 \mathrm{~W}$ had no impact on the pectinase activity (Figure 1b). 

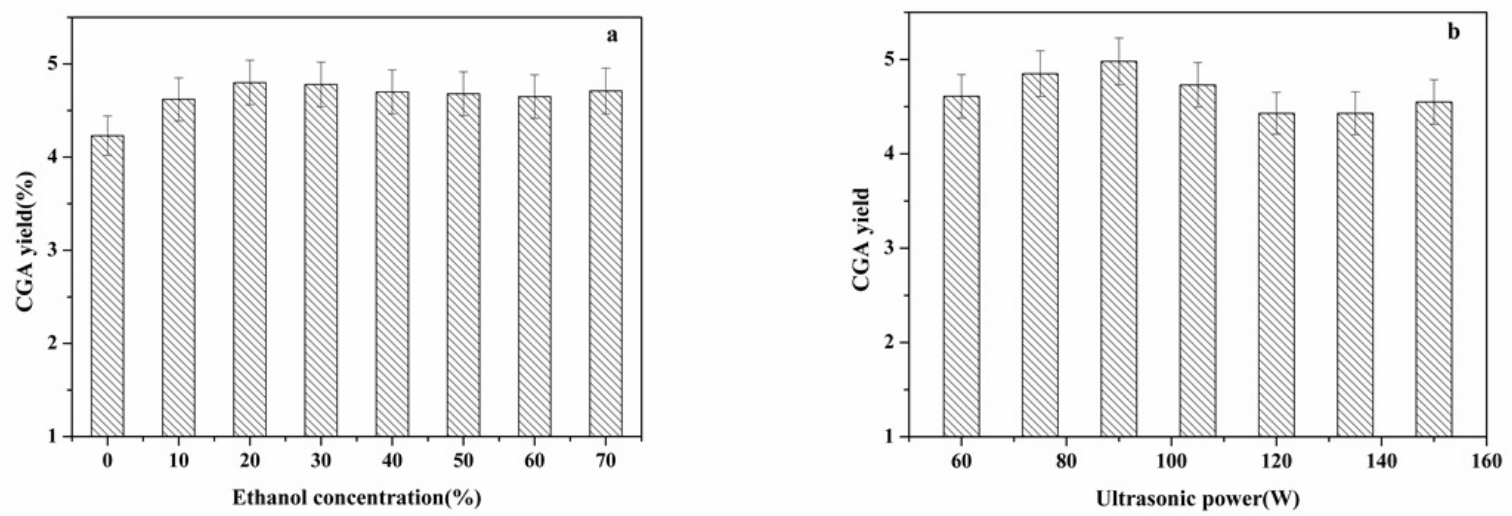

Figure 2: (a) Effect of ethanol concentrations on the extraction yields (b) and ultrasonic power on the extraction yields of CGA from FLJ.

However, the pectinase activity was rapidly decreased when the ultrasonic power was higher than $100 \mathrm{~W}$, while the CGA yield was slightly increased when that was higher than $140 \mathrm{~W}$. This indicated that ultrasonic power played a role in the deactivation of pectinase. The activity of pectinase completely diminished when the ultrasonic power was higher than $150 \mathrm{~W}$.

Effect of pectinase concentration on CGA yield: The pectinase concentration considerably affected the CGA yield. Owing to its ability to accelerate the dissolution of cell contents, pectinase had been widely used to digest plant cell wall [12]. The influence of pectinase concentration on CGA yield was investigated under the following conditions of ultrasonic temperature $40^{\circ} \mathrm{C}, 20 \%(\mathrm{v} / \mathrm{v})$ ethanol concentration, ultrasonic power $90 \mathrm{~W}$, liquid-solid ratio $40 \mathrm{ml} / \mathrm{g}$, ultrasonic time $40 \mathrm{~min}$ and $\mathrm{pH}$ 3. From Figure 3a, the yield reached a maximum value when pectinase concentration was increased to 0.25 $\mathrm{mg} / \mathrm{ml}$ and remained essentially unchanged at pectinase concentration higher than $0.25 \mathrm{mg} / \mathrm{ml} .0 .25 \mathrm{mg} / \mathrm{ml}$ was considered as the optimal concentration for PUSE taking the cost into account.

Effect of liquid-solid ratio on CGA yield: A series of experiments were carried out for finding a proper liquid-solid ratio. The influence of liquid-solid ratio on CGA extraction yield was investigated under the following conditions of ultrasonic temperature $40^{\circ} \mathrm{C}, 20 \%(\mathrm{v} / \mathrm{v})$ ethanol concentration, ultrasonic power $90 \mathrm{~W}, 0.25 \mathrm{mg} / \mathrm{ml}$ pectinase concentration, ultrasonic time $40 \mathrm{~min}$ and $\mathrm{pH}$ 3. From Figure $3 \mathrm{~b}$, the CGA yield was greatly increased with increasing liquid-solid ratio from 20 to $50 \mathrm{ml} / \mathrm{g}$. It is likely that the interactions between FLJ and solvent increase with increasing amount of solvent [22].

It appeared that the interactions between sample and solvent reached saturated state when the liquid-solid ratio exceeded $50 \mathrm{ml} / \mathrm{g}$. Considering the cost, $50 \mathrm{ml} / \mathrm{g}$ was chosen as the optimum liquid-solid ratio.

Effect of ultrasonic time on CGA yield: From Figure 3c, the influence of ultrasonic times on CGA yields was evaluated under the following conditions of ultrasonic temperature $40^{\circ} \mathrm{C}, 20 \%(\mathrm{v} / \mathrm{v})$ ethanol concentration, ultrasonic power $90 \mathrm{~W}$, pectinase concentration $0.25 \mathrm{mg} / \mathrm{ml}$, and $\mathrm{pH}$ value 3 . The results in Figure $3 \mathrm{c}$ illustrated that the CGA yield increased with increasing extraction time of up to $50 \mathrm{~min}$, whereas that decreased with increasing extraction time higher than 50 min.

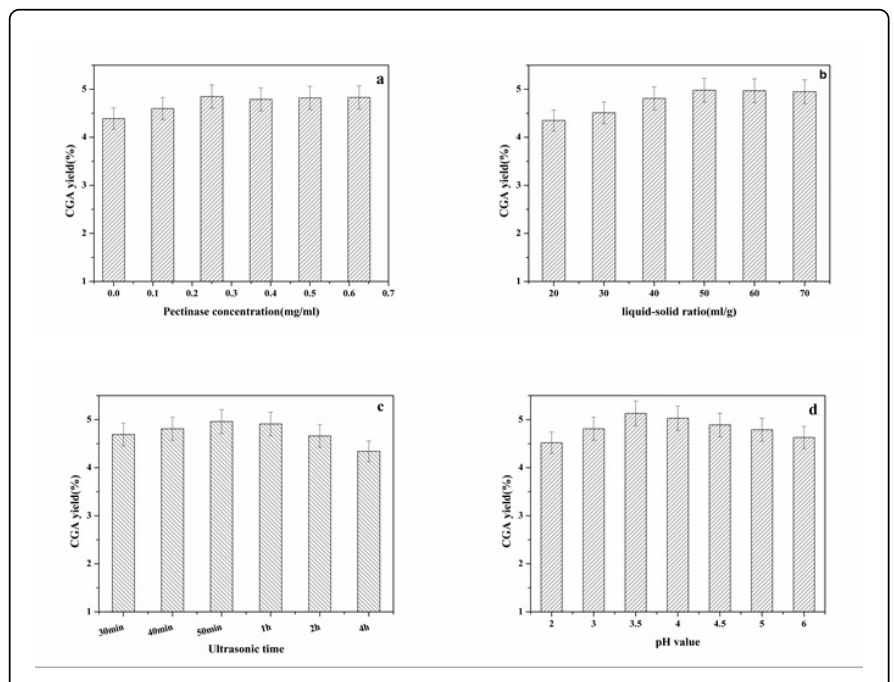

Figure 3 Effects of pectinase concentration (a) liquid-liquid ratio; (b) ultrasonic time; (c) and $\mathrm{pH}$; (d) on the extraction yields of CGA from FLJ.

The results indicated that extended ultrasonic time provided more thorough interactions between the solvent and FLJ, however, extended time may destruct the chemical structure of the extract. Thus, 50 min was selected as the optimal time used in subsequent experiments.

Effect of $\mathrm{pH}$ value on CGA yield: The effects of $\mathrm{pH}$ range of 2.0-6.0 were investigated considering that CGA is an acidic compound and $\mathrm{pH}$ had been found to have important effect on pectinase. The experimental conditions were as follows of ultrasonic temperature $40^{\circ} \mathrm{C}, 20 \% \quad(\mathrm{v} / \mathrm{v})$ ethanol concentration, $0.25 \mathrm{mg} / \mathrm{ml}$ pectinase concentration, liquid-solid ratio $50 \mathrm{ml} / \mathrm{g}$, ultrasonic time $50 \mathrm{~min}$ and ultrasonic power $90 \mathrm{~W}$. The results in Figure $3 \mathrm{~d}$ showed that the extraction efficiency of CGA initially increased with the increase of $\mathrm{pH}$ and reached maximum CGA yield at $\mathrm{pH} 3.5$, while the efficiency decreased with $\mathrm{pH}$ beyond 3.5. It appears that the increase of $\mathrm{pH}$ is beneficial to the ionization of CGA; thereby the H-bond between 
Citation: Sun Y, Chen H, Xu C, Yu D, Hu Y (2018) Pectinase-Ultrasound Synergistic Extraction of Chlorogenic Acid from Flos Lonicera Japonicae. J Bioprocess Biotech 8: 333. doi:10.4172/2155-9821.1000333

Page 4 of 5

solvent and CGA is weakened [23-25]. Thus, pH 3.5 was considered most suitable for the extraction experiments.

Comparison with reference methods: The GCA yield obtained in the present study was compared with the previous reported methods.
The comparison listed in Table 1 indicated that our method has superior extraction efficiency with higher yields than other reported methods.

\begin{tabular}{|l|l|l|}
\hline Method & Optimized extraction parameters & CGA yield(\%) \\
\hline WE & Liquid ratio $15 \mathrm{ml} / \mathrm{g}$, extraction temperature $70^{\circ} \mathrm{C}$, extraction time $1 \mathrm{~h}$ & $3.8[24]$ \\
\hline REE & Ethanol concentration $80 \%(\mathrm{v} / \mathrm{v})$, liquid- solid ratio $30 \mathrm{ml} / \mathrm{g}$, extraction time $70 \mathrm{~min}$, extraction temperature $90^{\circ} \mathrm{C}$. & $3.63[25]$ \\
\hline MAE & Extraction time $30 \mathrm{~min}$, ethanol concentration $75 \%$, liquid- solid ratio $30 \mathrm{ml} / \mathrm{g}$, extraction temperature $65^{\circ} \mathrm{C}, \mathrm{pH} 7$ & $5.07[18]$ \\
\hline EAE & Dosage of cellulase $3.0 \%$, extraction temperature $46^{\circ} \mathrm{C}$, extraction time $4 \mathrm{~h}$, leaching at $56^{\circ} \mathrm{C}$ for $1 \mathrm{~h}$. \\
\hline UAE & Dosage of pectinase $0.5 \%$, operating temperature $45^{\circ} \mathrm{C}$, operating time $120 \mathrm{~min}, \mathrm{pH} 5.0$. \\
\hline PUSE & $\begin{array}{l}\text { Ultrasonic temperature } 40^{\circ} \mathrm{C}, \text { ultrasonic power } 280 \mathrm{~W}, \text { ultrasonic time } 80 \mathrm{~min}, \text { ethanol concentration } 70 \%, \text { liquid- } \\
\text { solid ratio } 30 \mathrm{ml} / \mathrm{g} .\end{array}$ & 4.37 \\
\hline $\begin{array}{l}\text { Ultrasonic temperature } 40^{\circ} \mathrm{C}, \text { ethanol concentration } 20 \%(\mathrm{v} / \mathrm{v}), \text { ultrasonic power } 90 \mathrm{~W}, \text { ultrasonic time } 50 \mathrm{~min}, \\
\text { pectinase concentration } 0.25 \mathrm{mg} / \mathrm{ml}, \text { liquid- solid ratio } 50 \mathrm{ml} / \mathrm{g}, \mathrm{pH} 3.5 .\end{array}$ & 5.13 \\
\hline
\end{tabular}

Table 1: Comparison of PUSE with the reference and conventional methods.

Scanning electron micrographs (SEM) of FLJ samples: As a result of PUSE process, the SEM showed the structural change of FLJ and revealed the extraction mechanism. Figure 4 showed the SEM of untreated sample, sample treated with ultrasound, sample treated with pectinase, sample treated with PUSE. Figure 4a illustrated the leaves of the untreated samples had clear and smooth surface. The ultrasound treatment caused the surface become rough with apparent fractures in some locations from Figure $4 \mathrm{~b}$.

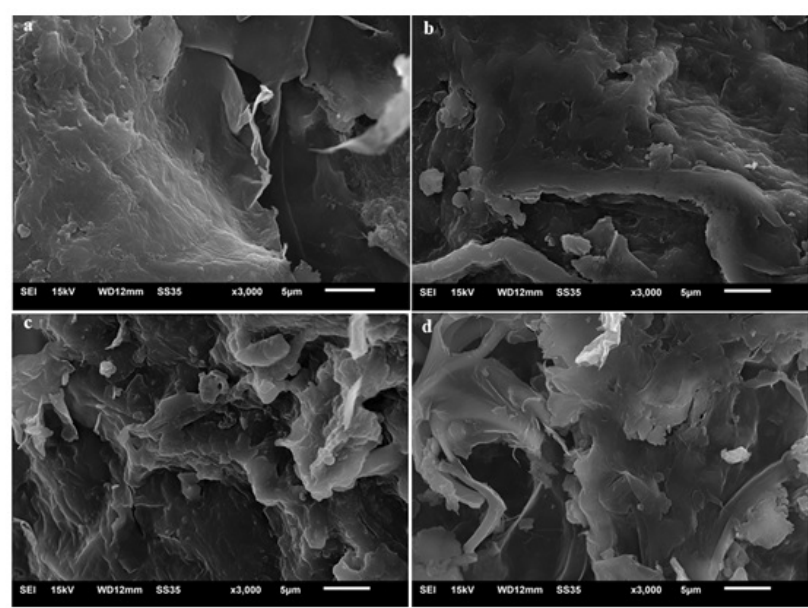

Figure 4: The scanning electron micrographs of FLJ, Untreated sample (a) treated only with ultrasound; (b) treated only with pectinase; (c) and treated with PUSE.

The SEM of the sample treated with pectinase showed that the surface was largely uneven with some wrinkles, which may be the result of the exposure to extraction solution from Figure 4c. The sample treated with PUSE had slightly rough sheet-like surface that appeared to be thinner compared with other samples and most of the bulges were disappeared. The breakage of plant cell and the degree of protrusions of extraction solvent were linked to the dissolution and extraction effectiveness. These findings indicated that the PUSE method caused the destruction of FLJ cell wall to a large extent, which led increasing of CGA extraction yield.

\section{Conclusions}

In the present study, a novel pectinase-ultrasound synergistic extraction (PUSE) was developed for the first time to extract CGA from FLJ. Compared to other reported extraction methods, the PUSE method showed higher extraction efficiency and yield. The finding indicates PUSE can be a highly potential method for extraction of biologically active compounds from natural resources.

\section{Acknowledgements}

The authors thank anonymous reviewers for their insightful comments and careful corrections. We also express our thanks to the supports from National Natural Science Foundation of China (21676143), Qing Lan Project of Jiang Su Province and Program for Innovative Research Team in University of Jiangsu Province.

\section{References}

1. Xiang Z, Ning Z (2008) Scavenging and antioxidant properties of compound derived from chlorogenic acid in south-China honeysuckle. LWT Food Sci Technol 41: 1189-1203.

2. China Pharmacopoeia Committee (2005) China Chemical Industry Press. Beijing 152: 291-292.

3. Shang X, Pan H, Li M, Miao X, Ding H (2006) Lonicera japonica Thunb.: ethnopharmacology, phytochemistry and pharmacology of an important traditional Chinese medicine. J Ethnopharmacology 138: 1-21.

4. Wang L, Weller CL (2006) Recent Advances in Extraction of Nutraceuticals from Plants. Trends in Food Sci Tech 17: 300-312.

5. Tajik N, Tajik M, Mack I, Enck P (2017) The potential effects of chlorogenic acid, the main phenolic components in coffee, on health: a comprehensive review of the literature. European J N 56: 2215-2244.

6. Zhao Y, Wang J, Ballevre O, Luo H, Zhang W (2012) Antihypertensive effects and mechanisms of chlorogenic acids. Hypertension Res 35: 370. 
Citation: Sun Y, Chen H, Xu C, Yu D, Hu Y (2018) Pectinase-Ultrasound Synergistic Extraction of Chlorogenic Acid from Flos Lonicera Japonicae. J Bioprocess Biotech 8: 333. doi:10.4172/2155-9821.1000333

Page 5 of 5

7. Mazvimba MT, Ying YU, Cui ZQ, Zhang Y (2012) State-of-the-Art Technologies for Separation of Azeotropic Mixtures. Chin J Nat Medicines 10: 311-320.

8. Wang X, Xiao KJ (2009) A Pilot-Plant Study of Continuous Ultrasonic Extraction of Soybean Protein. Food Sci 12: 230-234.

9. Cao Y, Li CJ, Xia ZN, Xu YQ, Zhang YM (2008) Effect of CU/5-FU on proliferation of gastric cancer cell line MKN45. Lishizhen Med Materia Medica Res 12: 2857-2858.

10. Baby KC, Ranganathan TV (2016) Effect of enzyme pre-treatment on extraction yield and quality of cardamom (Elettaria cardamomum maton.) volatile oil. Ind Crop Prod 89: 200-206.

11. Wu ML, Zhou CS, Chen LS, Zhong SA, Gu FF (2004) MicroRNA interference technologies. Nat Prod Res Dev 6: 557-560.

12. Zheng XQ, Jiang JF, Liu XL, Sun XY (2006) Ionic liquid-based enzymeassisted extraction of chlorogenic acid from Flos Lonicera Japonicae. Food Sci 27: 159-161.

13. Wu JW, Luo YJ, Wu X, Li XM (2006) Study on extraction process of honeysuckle aqueous extracts to optimize focculation by uniform design method. Chin J Vet Drug 40: 23-25.

14. Lan WU, Zhang ZS (2005) Extraction and Examination of Chlorogenic Acid from Flos Lonicerae. Food Sci 26: 130-134.

15. Lu DW, Zhang T, Li HY (2015) Study on extraction process of chlorogenic acid in Flos Lonicerae. Guangdong Chem Ind 42: 40-41.

16. Xiao WP, Li J (2011) Extraction and Quantitative Determination of Chlorogenic Acid from Flos Lonicerae Japonicae. Anhui Agric Sci 39: 21675-21676.
17. Upadhyay R, Ramalakshmi K, Rao LJM (2012) Microwave-assisted extraction of chlorogenic acids from green coffee beans. Food Chem 130: 184-188.

18. Li WL, Hou T (2013) Study on microwave assisted extraction of chlorogenic acid from Flos Lonicerae. Feed Anim Husb New Feed 5: 35-38.

19. Han AX, Ren YR (2009) Food Sci Tech 8: 138-141.

20. Serpone N, Olarusso P (1995) Cheminform 20: 635-679.

21. Zhang ZS, Wang LJ, Li D, Jiao SS, Chen XD, et al. (2008) Ultrasoundassisted extraction of oil from flaxseed. Separ Purific Tech 62: 192-198.

22. Sancheti S, Sancheti S, Bafna M, Kim HR, You YH, et al. (2011) Evaluation of antidiabetic, antihyperlipidemic and antioxidant effects of Boehmeria nivea (L.) Gaudich., Urticaceae, root extract in streptozotocin-induced diabetic rats. Brazilian Journal Pharmacogno 21: 146-154.

23. Tan Z, Li F, Xing J (2011) Separation and purification of aloe anthraquinones using PEG/salt aqueous two-phase system. Separ Sci Tech 46: 1503-1510.

24. $\mathrm{Li} \mathrm{Z}, \mathrm{Li} \mathrm{N}$, Zhao $\mathrm{TH}$ (2011) Optimization of extraction process of chlorogenic acid from honeysuckle by orthogonal test. J Chengde Med College 28: 12-14.

25. Mei L (2007) Toothpaste Industry 32: 30-34. 